\title{
P68 RNA helicase as a molecular target for cancer therapy
}

\author{
Ting-Yu Dai, Liu Cao, Zi-Chen Yang, Ya-Shu Li, Li Tan, Xin-Ze Ran ${ }^{*}$ and Chun-Meng Shi*
}

\begin{abstract}
The DEAD-box family of RNA helicase is known to be required in virtually all cellular processes involving RNA, and p68 is a prototypic one of the family. Reports have indicated that in addition to ATPase and RNA helicase ability, p68 can also function as a co-activator for transcription factors such as estrogen receptor alpha, tumor suppressor p53 and beta-catenin. More than that, post-translational modification of p68 including phosphorylation, acetylation, sumoylation, and ubiquitylation can regulate the coactivation effect. Furthermore, aberrant expression of p68 in cancers highlights that p68 plays an important role for tumorgenesis and development. In this review, we briefly introduce the function and modulation of p68 in cancer cells, and put forward envisagement about future study about p68.
\end{abstract}

Keywords: RNA helicase, p68, Molecular target, Transcriptional co-activator

\section{Introduction}

The DEAD-box family of RNA helicases contains nine domains of strong peptide sequence conservation, including the Asp-Glu-Ala-Asp (DEAD) helicase signature sequence. In addition to regulating the conformation of RNA structure and the known ATP-dependent RNA helicase activity [1], DEAD box-containing proteins are required for a variety of processes involving RNA like ribosome biogenesis, embryogenesis, spermatogenesis, and cell development and division [2].

P68 (DDX5) is considered as a prototypic member of the DEAD-box family of RNA helicases. It was fortuitously discovered through a cross-reaction with an antibody against the simian virus SV-40 T antigen, and shows extensive amino-acid sequence homology to eukaryotic translation initiation factor eIF-4A, the first identified helicase capable of unwinding RNA [3]. In no time, p68 was reported to be an RNA-dependent ATPase and has RNA-unwinding activity [4].

Many research studies demonstrated that p68 is important for a diverse range of cellular processes, including pre-mRNA, rRNA and miRNA processing and transcription [5]. Furthermore, the existence of p68 and the highly related DEAD box family member p72 can be

\footnotetext{
*Correspondence: ranxinze@163.com; shicm@sina.com

Institute of Combined Injury, State Key Laboratory of Trauma, Burns and Combined Injury, Chongqing Engineering Research Center for

Nanomedicine, Department of Preventive Medicine, Third Military Medical University, Chongqing 400038, China
}

found in a diversity of complexes in the cell, together with other factors [6]. There is a considerable body of evidence indicating that p68 is an important co-activator of transcription factors, for example, estrogen receptor $\alpha$ (ER $\alpha$ ) [7], MyoD [8], Runx2 [9], androgen receptor (AR) [10], and p53 [11], which have shown clear significance in cancer. Recent studies have also demonstrated that p68 is aberrantly expressed/modified in several types of cancers, suggesting that p68 plays important roles in cancer development and progression [12].

For an illuminating purpose for cancer therapeutic utilization, we summarize the structural and functional characteristics of p68 in both biological and pathological conditions, which will highlight the potential target for anticancer therapy.

\section{Structure characteristics and biological functions of p68(DDX5)}

P68 shares a "helicase core" of nine conserved motifs with other members of the DEAD-box family, and these conserved regions are critical for RNA binding, ATP binding and hydrolysis, and intermolecular interactions [13]. The core is divided into two flexibly linked RecAlike domains, Domain 1(D1) and domain 2(D2). The D1, consisting of Q-motif, motifs I, II and III, serves for ATP-binding. The D2, including motifs IV, V and VI, exhibits an RNA-duplex recognition domain [14]. The Q-motif is present at the $\mathrm{N}$-terminus of the catalytic core 
and is preceded by a conserved phenylalanine 17 amino acids at the upstream [15]. This conserved aromatic group and the Q-motif are identified as adenine recognition motif and can regulate ATP binding and hydrolysis [16]. Further, the Q-motif was reported to affect the helicase activity through regulating the affinity between the protein with RNA substrates [17]. Motifs I and II (or Walker A and B) are capable of binding ATP. The energy from ATP hydrolysis is coupled to RNA unwinding by motif III and cooperates with other motifs to create a high-affinity RNA binding site [18]. And motif IV, together with motif Ia, $\mathrm{Ib}$ and V, is engaged in ATP-dependent binding of RNA substrates [19]. Obviously, the structure of p68 is in a dominant position in the representation of function, and there is a profound work which is remained to elucidate the mechanism between structure and biological activity [20] (Figure 1).

As is known to all, p68 is a prototypic multifunctional protein, and the most well recognized function of p68 is to bind both double- and single-stranded RNA and provide energy to perform bidirectional RNA duplex unwinding activity as an ATPase [21]. Another important function of p68 is for efficient spliceosome assembling and RNA splicing [22]. Previous investigations demonstrated that p68 could unwind and separate the connection between the U1 small nuclear ribonucleoprotein particle and the 5' splice site, facilitating the dynamic formation from pre-spliceosome to spliceosome [23]. However, the assembly of the spliceosome is in an RNA helicaseindependent manner [24]. RNA helicase p68 could also manifest conformational change activity enhancing the U1-5'ss interaction [25]. Based on the observation, the p68 is important for RNA maturation. In succession, alternative splicing can also be regulated in this way [26].
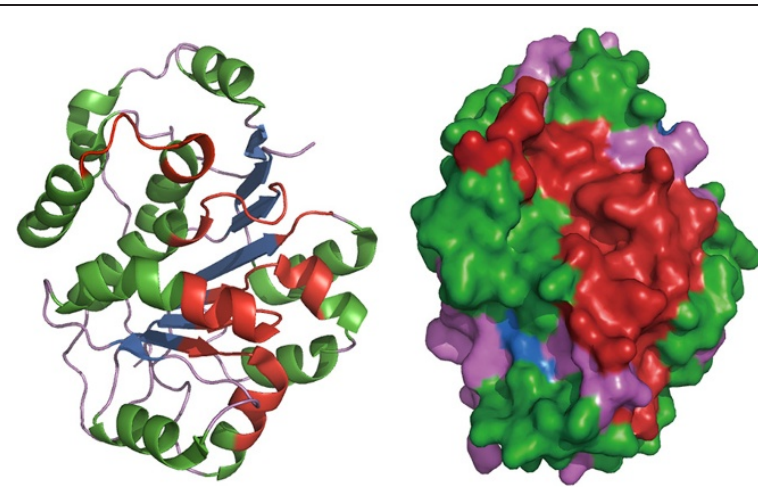

Figure 1 Stereoview of secondary structure of the $\mathrm{N}$-terminal domain of the human DEAD-box RNA helicase DDX5(P68). left ribbon and helix diagram; right: surface representation. Different secondary structures are marked by different colors. The conserved motifs are colored red. They are successive and converge on one side of the surface of the overall structure. The functional area can be modified or combined with other proteins. (PDB ID: 4A4D).
MicroRNAs(miRNAs) are small non-coding RNAs that can affect cell development through regulating protein expression or messenger RNA synthesis [27]. The primary miRNA (pri-miRNA) is cleaved by the nuclear RNase III endonuclease Drosha in the cell nucleus and transitions to precusor miRNA (pre-miRNA) which in sequence will be transported to cytoplasm [28]. Afterwards, the pre-miRNA is processed by another nuclear RNase III endonuclease Dicer into mature double-strand miRNA. The Drosha forms two multi-protein complexes, and experimental results revealed that p68 is a component of the larger one [29]. Moreover, p68 can function as a recognizer of pri-miRNA and bind to the specific structure [30]. It suggests that p68 is required in the early stages of miRNA biogenesis involving the processing of pri-miRNA to pre-miRNA. Recently, much work has been done in the field of miRNA processing regulated by Drosha. The transforming growth factor $\beta(\mathrm{TGF} \beta)$ signal transducers, Smad protein, as well as the tumor suppressor p53, has been reported to recruite into Drosha by interaction with p68, facilitating accumulation of Drosha complex to specific pri-miRNA [31]. However, the Smad and p53 are probably in competition for p68 binding and thus maturation of miRNA is dynamically modulated by these proteins [32].

It also has been indicated that p68 is required in rRNA processing [33]. In the early stage of ribosome biogenesis in nucleolus, p68 is related to the restructuring of $32 \mathrm{~S}$ pre-rRNA [34]. And in the following steps, the p68 is exported from nucleoli and has been shown to be associated with nucleoplasmic processing of $5.8 \mathrm{~S}$ pre-ribosomes [30]. Nucleophosmin (NPM) (B23) is a nucleolus/nucleuscytoplasm shuttling protein and is indispensable in cell development and proliferation. The fundamental function of NPM is to transport ribosomes and ribosomal subunits from nucleus to cytoplasm, and p68 is an important binding protein of it [35]. The tumor suppressor ARF, which inhibits cell cycle, has been considered as a hinder of exportation to suppress rRNA biogenesis by associating with NPM [36]. Consistent with the appearance, the ARF is also a blocker in the interaction between p68 and NPM, and effects the production of mature rRNA [37].

\section{Abnormal expression of p68 in cancer}

Since p68 is ubiquitously expressed in human tissues and plays a multifunctional role in a number of the cellular processes, many experimental results revealed examples of diseases concerned with p68, including obesity [38], Down syndrome [39], myotonic dystrophies [40] and especially cancer [5]. Over the past few decades, abnormal expression of p68 has been detected in many cancers, such as colon cancer [41], breast cancer [42], lung cancer [43], cutaneous squamous cell carcinoma [44], leukemia [45] and so on (Table 1). 
Table 1 Aberrant expression of p68 in cancer

\begin{tabular}{|c|c|c|c|}
\hline Type of tumor & Expression level of p68 & Involved factor & Author/reference \\
\hline \multirow[t]{3}{*}{ Colorectal cancer } & \multirow{2}{*}{$\begin{array}{l}\text { elevated in HCT-116, LoVo, SW480 and SW620 cell lines relative to } \\
\text { normal colon cell lines }\end{array}$} & \multirow[t]{3}{*}{$\beta$-catenin, p21 } & Singh C et al., 1995 [41] \\
\hline & & & Shin S et al., 2007 [46] \\
\hline & $\begin{array}{l}\text { higher p68 positive rate of adenocarcinoma than matched normal tissue, } \\
\text { and the expression degree increases from polyp to adenoma and } \\
\text { adenocarcinoma in sequence }\end{array}$ & & Causevic M et al., 2001 [47] \\
\hline \multirow[t]{3}{*}{ Breast cancer } & $\begin{array}{l}\text { increased progressively from the luminal to basal breast cancer cell } \\
\text { lines( } 38 \text { cell lines) }\end{array}$ & \multirow[t]{3}{*}{ miR-182,ERa } & Haines GK et al., 1996 [42] \\
\hline & elevated in cancer tissue than in normal breast tissue & & Wang D et al., 2012 [48] \\
\hline & higher DDX5 positive rate in malignant biopsies than benign & & Fujita T et al., 2003 [49] \\
\hline $\begin{array}{l}\text { Head and neck squamous } \\
\text { cell carcinoma }\end{array}$ & $\begin{array}{l}\text { elevated in (UMSCC)-10B and (UTSCC)-19A cell lines compared two benign } \\
\text { epithelial keratinocytes }\end{array}$ & Not determined & Beier UH et al., 2006 [50] \\
\hline Prostate cancer & higher $\mathrm{p} 68$ positive rate in $\mathrm{PCa}$ biopsies than in $\mathrm{BPH}$ & AR & Clark EL et al., 2008 [10] \\
\hline $\begin{array}{l}\text { Salivary gland } \\
\text { pleomorphic adenomas }\end{array}$ & elevated in adenoma than matched normal salivary gland tissue & Not determined & Zhang X et al., 2009 [51] \\
\hline \multirow[t]{2}{*}{ Leukemia } & $\begin{array}{l}\text { higher level in SupT1, DND41, HBP-ALL, KOPT1, Jurkat, MOLT4, MOLT13, } \\
\text { MOLT15 and REX cell lines than selected acute myeloid leukemia cell lines }\end{array}$ & \multirow[t]{2}{*}{ NOTCH1, MAML1 } & \multirow[t]{2}{*}{ Lin S et al., 2012 [45] } \\
\hline & $\begin{array}{l}\text { elevated in human T-ALL bone marrow samples compared with normal } \\
\text { T cells }\end{array}$ & & \\
\hline \multirow[t]{2}{*}{ Glioma } & elevated in H-4, HS-683, U-87, U-251, and U-343 cell lines & \multirow[t]{2}{*}{ NF-kappaB, p50 } & \multirow[t]{2}{*}{ Wang R et al., 2012 [52] } \\
\hline & $\begin{array}{l}\text { elevated in high-grade human glioma relative to low-grade glioma and } \\
\text { normal adjacent brain tissue }\end{array}$ & & \\
\hline \multirow{2}{*}{$\begin{array}{l}\text { Cutaneous squamous } \\
\text { cell carcinoma }\end{array}$} & elevated in carcinoma than adjacent tissues and normal foreskin tissues & \multirow[t]{2}{*}{ Not determined } & \multirow[t]{2}{*}{ Wang SJ et al., 2012 [44] } \\
\hline & higher in carcinoma cases with metastasis than those without metastasis & & \\
\hline Hepatocellular carcinoma & $\begin{array}{l}\text { down-regulated in HBV-positive and NBNC HCC tissues compared with } \\
\text { matched adjacent non-cancerous liver }\end{array}$ & Not determined & Kitagawa N et al., 2013 [53] \\
\hline
\end{tabular}

A clinical cohort study on prostate cancer (PCa) showed that the p68 expression in the PCa biopsies was markedly higher than matched benign prostatic hyperplasia $(\mathrm{BPH})$ [10]. It is consistent with previous work, which also provided analogous comparison result between colon cancer and normal tissues, and this study further showed that defect in proteasomal degradation contributes to p68 accumulation [47]. And then, an additional research showed that post-translational modification, like sumoylation and ubiquitylation, would strengthen the stability of p68 [54]. Dysregulation of p68 expression may influence the miRNA processing machinery and promote benign tumor development [51]. And in cancers, the up-regulation of p68 is detected in both invasive and periphery normal tissues, suggested its early occurrence during tumor development [47]. Moreover, some experimental results indicated that the expression is associated with poor prognosis and probably resistance to therapy $[52,53]$, which highlight the possible role of p68 in selection of anticancer therapy and prediction of overall survival.

P68 as a transcriptional co-activator in tumor development P68 is also an important transcriptional regulator, acting both as a transcriptional co-activator for a diverse range of transcription factors including estrogen receptor
$\alpha(E R \alpha)$ [55], the tumour suppressor p53 [11] and the myogenic regulatory factor MyoD [56]. Meanwhile, in other conditions, as a promoter-dependent transcriptional repressor [57].

\section{Estrogen receptor co-activator}

The estrogen receptor $\alpha$ is a member of the nuclear hormone receptor family of transcription factors that is activated by estrogen, and can regulate mammary gland development. Much work has been reported recently that ER $\alpha$ contributes a lot to the development and progression of breast cancer [58]. SRC-1/TIF2 family proteins is a part of the nuclear receptor AF-2 co-activator complexes with $\mathrm{CBP} / \mathrm{p} 300$ and an RNA co-activator, SRA. And it is reported that p68/p72 can directly bind the SRC-1/TIF2 family proteins and interact with $\mathrm{p} 72 / \mathrm{p} 68$ [59]. In addition, another study showed that p68/p72 can cooperate with SRC-1 and interact with ER $\alpha$ in an estrogenindependent manner [60]. Based on these reports, p68/ p72, in synergy with ER $\alpha, C B P / p 300, M y o D$, can form a component of the ER $\alpha$ transcriptional complex. This indicates that p68 and p72 are important components of the transcription machinery. So further study of p68 will provide more evidences of p68 playing an important role in breast cancer development and/or progression. 


\section{Androgen receptor}

The androgen receptor (AR) belongs to the nuclear steroid hormone receptor family. It is an androgen-dependent transcription factor which play an essential role in the development and progression of prostate cancer $(\mathrm{PCa})$. A number of androgen receptor (AR) transcriptional co-regulators have been identified to play important roles in prostate cancer (PCa). The p68 possess a LxxLL motif which is observed in cofactors that interact with ligand-activated nuclear hormone receptors [61]. What's more, p68 was found to be over-expressed in prostate cancers, to interact with AR, enhance AR transcriptional activity in luciferase reporter assays and to be recruited to the AR-responsive prostate specific antigen (PSA) promoter in the presence of RNAP II [62]. P68 siRNA knockdown also resulted in decreased expression of ARresponsive genes [10]. The observation demonstrate that p68 is a co-activator of the AR, independent of the p68 helicase function and c-Abl activity. So the abnormal regulation of p68 may affect the function of AR influencing the development and progression of prostate cancer.

\section{P53}

P53 is now well established as an anti-oncogene, and p68 was found to be recruited to p53-responsive promoters in response to DNA damage, and also to the $\mathrm{p} 21$ promoter facilitating transcriptional initiation [11]. This would upregulate the level of $\mathrm{p} 21$. Meanwhile, the acceleration of 221 results in more forming of cyclin D1/Cdk2 complexes, which can phosphorylate the retinoblastoma protein $(\mathrm{pRb})$ [63]. Rb works as a regulator of the cell cycle, controlling passage through G1 phase [64]. And the unphosphorylated $\mathrm{Rb}$ would combine with the E2F transcription factors to block cell cycle [65]. It is consistent with previous work, which showed that p68 is over-expressed in cancer cells. Taken together, it seems that the p68 could regulate the cancer cell cycle.

P53 has multiple splicing variants. $\Delta 133$ p53 is one of the protein isoforms from mRNA variants, while it turns to negatively regulate the apoptosis mediated by p53 [66]. Experiments in breast cancer indicated that the expression of $\Delta 133 \mathrm{p} 53$ is up-regulated in p53-independent manner with p68 siRNA knockdown, and could inhibit the ability of p68 to coactivate p53-dependent induction to the cell cycle inhibitor p21 [67]. Recently, an additional research showed that p68 plays an essential role in recruitment of p53 to the p21 promoter, and selection of p53 function [68]. Taken together, we can construct a dynamic interaction among p68, p53 and p21. As we mentioned before, p53 could recruit to the Drosha complex through the association with p68 and facilitates the processing of primiRNAs to precursor miRNAs. And another study further shows that the recruitment forms through a carboxyterminal half of the central DNA-binding domain [31].
Based on previous work, we can suppose that p68 may contribute to the carcinogenesis by interact with p53, Drosha and other factors in the procedure.

\section{$\beta$-catenin}

$\beta$-catenin is a protein that can modulate both cell adhesion and gene transcription, and p68 may regulate the ability of $\beta$-catenin in different ways. It has been reported that p68 can form complex directly with $\beta$-catenin through its helicase domain and facilitate the transcription activation of $\beta$-catenin [46]. Besides, the phosphorylated p68 could regulate the transcription of $\beta$-catenin downstream effectors including c-Myc, cyclin D1 [69]. It also has been shown that the Wnt binds to receptors and co-receptors initiating the translocation of destruction complex, and nuclear localization of $\beta$-catenin [70]. And p68, cooperated with mrhl RNA, negatively regulated the Wnt signaling [71]. So it suggested that p68 plays an important role in the stabilization of $\beta$-catenin level. Recently, several work has been reported in the field of the p68- $\beta$-catenin signaling. For example, the platelet derived growth factor (PDGF), which is important for the development of prostate cancer, was reported to activate p68- $\beta$-catenin signaling in PCa cells [72]. Experiments also indicated that the p68 is positively correlated with endogenous $\beta$-catenin and modulate PDGF-BB induction of Mcl-1 (myeloid cell leukemia-1) expression [73].

Smad protein is an important signal transducer of TGF-beta, and the TGF-beta signaling can promote some specific miRNA maturation through the binding of Smad protein to the Drosha complex component p68 [32,74]. Recently, it has been discovered that the mesenchymal to epithelial transition(MET) can be induced in response to TGF-beta [75]. The mechanism is based on the interaction of some mesenchymal activators, including $\beta$ catenin, and the Smad protein to form an EMT promoting Smad complexes (EPSC) in tumors [76]. Consistent with the outcome, there were some other works demonstrated that the $\beta$-catenin-Smad complex could signal as a regulator to TGF-beta induced EMT $[77,78]$.

\section{Post-translational modification of p68 in cancer development and progression}

Experimental data have indicated that the protein kinase $\mathrm{C}(\mathrm{PKC})$ can phosphorylate p68 and the latter binds to calmodulin in a Ca2 +- dependent manner [79]. Now it is clearly that the p68 RNA helicase is a member of the IQ domain-containing family and the C-terminal domain of p68 is a substrate for PKC in the absence of RNA. But both phosphorylation and calmodulin binding are suppressors for p68 ATPase activity. And documents further showed that the C-terminal domain of p68 RNA helicase binds ssRNA [80]. In addition to the conserved motifs, there was an RGS-RGG motif identified as an 
RNA-binding domain of p68 [81]. Moreover, different phosphorylated residues may cause different decision on effects [82]. In conclusion, the main emphasis is placed on the topic on high correlation between phosphorylation of p68 and cancer development and progression, and more research is still required for the future diagnosis and therapy for cancer.

Post-translational modifications can extremely increase the diversity of protein in the progress of protein biosynthesis. Ubiquitylation, sumoylation and acetylation are also dominating modes for p68 modifications. Go on with the previous work, the over-accumulated p68 in variant cancers is then detected to be poly-ubiquitylated, and the expression distinguish between normal and tumor cells indicate that the ubiquitylation of p68 can be important for the tumorgenesis [47]. Meanwhile, sumoylation of p68/p72 is also upregulated. The sumoylation is considered as a multiple-effect modification. It is reported that SUMO (small ubiquitin-related modifier) modification can increase the stability of $\mathrm{p} 68$ and promote the binding to the acetyltransferase $\mathrm{p} 300$, furthermore, to regulate the activity of p53 and estrogen receptor [83]. Besides, SUMO modification is on a relative fixed site (K53) of p68, and can in bi-direction regulate its transcriptional repression activity and the ability as a co-activator of p53 [84]. In addition, both p68 and p72 can bind to the acetyltransferase p300, and the acetylation mediated by p300 resulted in aberrant activation of p68, promoting the interaction with HDACs [83]. We can conclude that the regulation and modification of p68 may be a way to mediate the tumor development.

\section{Emerging roles of p68 in cancer development and progression}

p68 is a promising research target for cancer, and the topic is investigated quite intensively in recent years. In addition to distinction in the expression of p68 between cancer and matched normal tissues, the expression level also varies with cancer cells in different states or degrees. For example, in cutaneous squamous cell carcinoma, the cancer tissue with metastasis has significantly higher than cases without metastasis [44]. Another documentation is the progressive increase of p68 expression level during the transition from polyp to adenoma, and then to adenocarcinoma in colon [46]. These details suggested that the RNA helicase p68 may play a vital role in regulating cancer cell grade and invasive potential.

The phosphorylation of p68 on Y593 contributes to the dissociation of $\beta$-catenin from the Axin destruction complex and translocation to nucleus, promoting EMT, which is always considered as an initiation of invasion and metastasis $[85,86]$. Further, the remodeling of cytoskeleton to form lamellipodia and filopodia is an essential step in migration progress. Experiment demonstrated that p68 could promote the deformation by cooperating with calmodulin, increasing the motility of cells [87]. Another previous experimental data also indicated that DDX5 plays a role in reorganization of actin cytoskeleton in breast

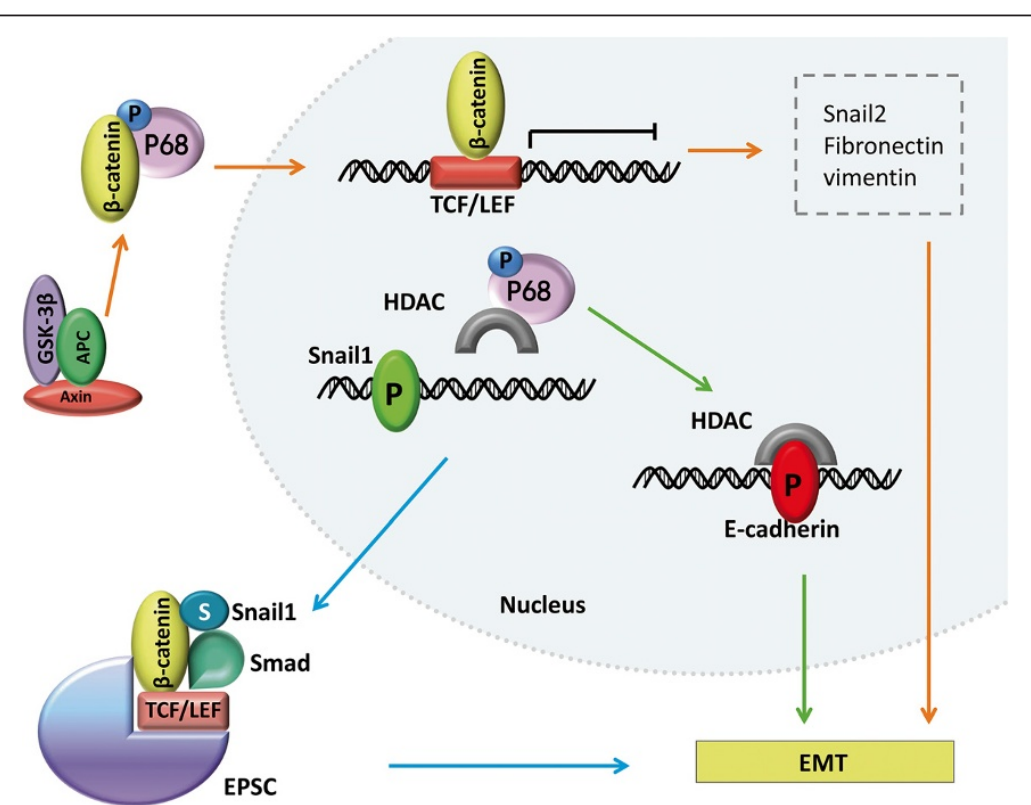

Figure 2 The mesenchymal to epithelial transition(MET) and p68. (orange line) The phosphorylated p68 dissociated $\beta$-catenin from Axin destruction complex to nucleus, blocking the transcription of TCF gene, and regulating EMT related genes such as Snail2, fibronectin and vimentin. (green line) The phosphorylated p68 deconstructed the interaction between HDAC and Snail 1 promoter, facilitating the binding of HDAC to the promoter of E-cadherin and blocking its transcription. (blue line) The destruction promoted the transcription of Snail 1 gene. The Smad protein, associated with TCF, Snail1, $\beta$-catenin and some other transcriptional factors to form EPSC in tumors. 
cancer [48]. Then we can figure out that p68 is involved in preparing fundamental conformational change for migration cells. p68 could also regulate invasiveness of cancer cells by interacting with other factors, including COUP-TFI in breast cancer [88] and a specific RNA aptamer in colon cancer [89]. A class of anticancer drugs histone deacetylase inhibitors (HDACIs), was found to have the ability to induce tumor cell EMT via the overaccumulation of Snail [90]. Recent study showed that phosphorylation of p68 at Y593 facilitate the deconstruction between histone deacetylase (HDAC) 1 and Snail promoter, initiating the transcription of Snail1 gene [91]. Then the upregulated Snail1 could block the transcription of E-cadherin by recruiting HDAC to the transcriptional promoter [92]. Combined with the observation on $\beta$-catenin, we can figure that phosphorylation of p68 regulate cancer development and metastasis potential (Figure 2).

Drug resistance is another important feature of cancer cells [93]. It also has been reported that RNA helicase p68 is phosphorylated at tyrosine residue in cancer cells, compared with matched normal tissue, and the treatment of TNF-alpha and TRAIL (Tumor necrosis factor-related apoptosis-inducing ligand, an anticancer agent) would weaken the effect of phosphorylation [94]. In succession, the team demonstrated that the phosphorylation of $\mathrm{p} 68$ on some specific residues mediates the effect of apoptosis agents [95]. For example, a double tyrosine phosphorylation of p68 at Y593 and Y595 induced by PDGF can extenuate resistance to apoptosis induced by TRAIL [96]. Therefore the phosphorylated p68 may have a certain protective effect on the activities of cancer cells.

With so many emerging implications of RNA helicase p68 in tumorgenesis and progression, we can demonstrate that p68 could be a potential target for cancer therapy.

\section{Conclusion}

As we have known, the modulation between p68 and the transcription factors may be involved with cancer metastasis potential and anticancer drug resistance. Unfortunately, although a lot of effort has been spent on the problem, the mechanism is still not so clear. In conclusion, we emphasize the possible oncogenic function of p68. Moreover, the niche-targeting regulation of p68 activation and expression may contribute to the possibility of blocking tumorgenesis and reinforcing the sensitivity of cancer cells to anticancer agents. So, further investigation of the mechanism of p68 promoting cancer development is highly significant for future fundamental and clinical medicine.

\section{Abbreviations}

ERa: Estrogen receptor a; MyoD: Myogenic differentiation antigen; Runx2: Runt-related transcription factor-2; AR: Androgen receptor; TGF $\beta$ : Transforming growth factor $\beta$; NPM: Nucleophosmin; ARF: Alternative reading frame;
PCa: Prostate cancer; BPH: Benign prostatic hyperplasia; SRC-1/TIF2: Steroid receptor co-activator-1/transcriptional intermediary factor 2; AF-2: Activation function-2; CBP: CREB-binding protein; SRA: Steroid receptor RNA Activator; PSA: prostate specific antigen; c-Abl: Abelson tyrosine kinase;

pRb: Retinoblastoma protein; E2F: E2 promoterbinding factor; PDGF: Platelet derived growth factor; Mcl-1: Myeloid cell leukemia-1; MET: Mesenchymal to epithelial transition; EPSC: EMT promoting Smad complexes; PKC: Protein kinase C; SUMO: Small ubiquitin-related modifier; HDAC: Histone deacetylase; COUP-TFI: COUP Transcription Factor 1; HDACl: Histone deacetylase inhibitor; TRAIL: Tumor necrosis factor-related apoptosis-inducing ligand, an anticancer agent; TCF: T-cell factor; HNSCC: Head and neck squamous cell carcinoma; T-ALL: T cell acute lymphoblastic leukemia; SCC: Squamous cell carcinoma; NBNC HCC: Non-hepatitis B virus/non-hepatitis C virus-related hepatocellular carcinoma.

\section{Competing interests}

The authors have declared that no competing interest exists.

\section{Authors' contributions}

TYD carried out collection and assembly of data, and manuscript writing. LC carried out the collection of data, and helped to draft the manuscript. YSL participated in the collection and assembly of data. ZCY participated in the collection and assembly of data. LT helped to modify the table and figure. XZR conceived of the review and helped to draft the manuscript. CMS conceived of the review and helped to draft the manuscript, and gave final approval of manuscript. All authors read and approved the final manuscript.

\section{Acknowledgments}

This work was supported by State Key Basic Research Development Program (2012CB518103), Natural Science Foundation Programs (81372727 and 81130026), Program of New Century Excellent Talents in University (NCET-11-0869) from Ministry of Education and Innovation team building program of Chongqing university (KJT201338).

Received: 14 May 2014 Accepted: 16 July 2014

Published online: 24 August 2014

\section{References}

1. Fuller-Pace FV: RNA helicases: modulators of RNA structure. Trends Cell Biol 1994, 4:271-274.

2. Schmid SR, Linder P: D-E-A-D protein family of putative RNA helicases. Mol Microbiol 1992, 6:283-291.

3. Lane DP, Hoeffler WK: SV40 large T shares an antigenic determinant with a cellular protein of molecular weight 68,000. Nature 1980, 288:167-170.

4. Iggo RD, Lane DP: Nuclear protein p68 is an RNA-dependent ATPase. EMBO J 1989, 8:1827-1831.

5. Fuller-Pace FV: DEAD box RNA helicase functions in cancer. RNA Biol 2013, 10:121-132.

6. Ogilvie VC, Wilson BJ, Nicol SM, Morrice NA, Saunders LR, Barber GN, Fuller-Pace FV: The highly related DEAD box RNA helicases p68 and p72 exist as heterodimers in cells. Nucleic Acids Res 2003, 31:1470-1480.

7. Endoh H, Maruyama K, Masuhiro Y, Kobayashi Y, Goto M, Tai H, Yanagisawa J, Metzger D, Hashimoto S, Kato S: Purification and identification of p68 RNA helicase acting as a transcriptional coactivator specific for the activation function 1 of human estrogen receptor alpha. Mol Cell Biol 1999, 19:5363-5372.

8. Caretti G, Schiltz RL, Dilworth FJ, Di Padova M, Zhao P, Ogryzko V, Fuller-Pace FV, Hoffman EP, Tapscott SJ, Sartorelli V: The RNA helicases p68/p72 and the noncoding RNA SRA are coregulators of MyoD and skeletal muscle differentiation. Dev Cell 2006, 11:547-560.

9. Jensen ED, Niu L, Caretti G, Nicol SM, Teplyuk N, Stein GS, Sartorelli V, van Wijnen AJ, Fuller-Pace FV, Westendorf JJ: p68 (Ddx5) interacts with Runx2 and regulates osteoblast differentiation. J Cell Biochem 2008, 103:1438-1451.

10. Clark EL, Coulson A, Dalgliesh C, Rajan P, Nicol SM, Fleming S, Heer R, Gaughan L, Leung HY, Elliott DJ, Fuller-Pace FV, Robson CN: The RNA helicase p68 is a novel androgen receptor coactivator involved in splicing and is overexpressed in prostate cancer. Cancer Res 2008, 68:7938-7946.

11. Bates GJ, Nicol SM, Wilson BJ, Jacobs AM, Bourdon JC, Wardrop J, Gregory DJ, Lane DP, Perkins ND, Fuller-Pace FV: The DEAD box protein p68: a novel transcriptional coactivator of the p53 tumour suppressor. EMBO J 2005, 24:543-553. 
12. Fuller-Pace FV, Moore HC: RNA helicases p68 and p72: multifunctional proteins with important implications for cancer development. Future Oncol 2011, 7:239-251

13. Linder P, Fuller-Pace F: Looking back on the birth of DEAD-box RNA helicases. Biochim Biophys Acta 2013, 8:750-755.

14. Mallam AL, Del Campo M, Gilman B, Sidote DJ, Lambowitz AM: Structural basis for RNA-duplex recognition and unwinding by the DEAD-box helicase Mss116p. Nature 2012, 490:121-125.

15. Andreou AZ, Klostermeier D: Conformational changes of DEAD-box helicases monitored by single molecule fluorescence resonance energy transfer. Methods Enzymol 2012, 511:75-109.

16. Tanner NK, Cordin O, Banroques J, Doere M, Linder P: The Q motif: a newly identified motif in DEAD box helicases may regulate ATP binding and hydrolysis. Molecular cell 2003, 11:127-138.

17. Cordin O, Tanner NK, Doere M, Linder P, Banroques J: The newly discovered Q motif of DEAD-box RNA helicases regulates RNA-binding and helicase activity. The EMBO journal 2004, 23:2478-2487.

18. Banroques J, Doere M, Dreyfus M, Linder P, Tanner NK: Motif III in superfamily 2 "helicases" helps convert the binding energy of ATP into a high-affinity RNA binding site in the yeast DEAD-box protein Ded1. J Mol Biol 2010, 396:949-966.

19. Banroques J, Cordin O, Doere M, Linder P, Tanner NK: A conserved phenylalanine of motif IV in superfamily 2 helicases is required for cooperative, ATP-dependent binding of RNA substrates in DEAD-box proteins. Mol Cell Biol 2008, 28:3359-3371.

20. Jankowsky E: RNA helicases at work: binding and rearranging. Trends Biochem Sci 2011, 36:19-29.

21. Hirling $H$, Scheffner $M$, Restle $T$, Stahl $H$ : RNA helicase activity associated with the human p68 protein. Nature 1989, 339:562-564.

22. Hamm J, Lamond Al: Spliceosome assembly: the unwinding role of DEAD-box proteins. Curr Biol 1998, 8:R532-R534.

23. Liu ZR: p68 RNA helicase is an essential human splicing factor that acts at the U1 snRNA-5' splice site duplex. Mol Cell Biol 2002, 22:5443-5450.

24. Lin C, Yang L, Yang JJ, Huang Y, Liu ZR: ATPase/helicase activities of p68 RNA helicase are required for pre-mRNA splicing but not for assembly of the spliceosome. Mol Cell Biol 2005, 25:7484-7493.

25. Kar A, Fushimi K, Zhou X, Ray P, Shi C, Chen X, Liu Z, Chen S, Wu JY: RNA helicase p68 (DDX5) regulates tau exon 10 splicing by modulating a stem-loop structure at the 5' splice site. Mol Cell Biol 2011, 31:1812-1821.

26. Guil S, Gattoni R, Carrascal M, Abian J, Stevenin J, Bach-Elias M: Roles of hnRNP A1, SR proteins, and p68 helicase in c-H-ras alternative splicing regulation. Mol Cell Biol 2003, 23:2927-2941.

27. $M a$ R, Jiang $T$, Kang $X$ : Circulating microRNAs in cancer: origin, function and application. J Exp Clin Cancer Res 2012, 31:38.

28. Zeng Y, Yi R, Cullen BR: Recognition and cleavage of primary microRNA precursors by the nuclear processing enzyme Drosha. EMBO J 2005, 24:138-148.

29. Gregory RI, Yan KP, Amuthan G, Chendrimada T, Doratotaj B, Cooch N, Shiekhattar R: The Microprocessor complex mediates the genesis of microRNAs. Nature 2004, 432:235-240.

30. Fukuda T, Yamagata K, Fujiyama S, Matsumoto T, Koshida I, Yoshimura K, Mihara M, Naitou M, Endoh H, Nakamura T, Akimoto C, Yamamoto Y, Katagiri T, Foulds C, Takezawa S, Kitagawa H, Takeyama K, O'Malley BW, Kato S: DEAD-box RNA helicase subunits of the Drosha complex are required for processing of rRNA and a subset of microRNAs. Nat Cell Biol 2007, 9:604-611.

31. Suzuki HI, Yamagata K, Sugimoto K, Iwamoto T, Kato S, Miyazono K: Modulation of microRNA processing by p53. Nature 2009, 460:529-533.

32. Davis BN, Hilyard AC, Nguyen PH, Lagna G, Hata A: Smad proteins bind a conserved RNA sequence to promote microRNA maturation by Drosha. Mol Cell 2010, 39:373-384.

33. Bond AT, Mangus DA, He F, Jacobson A: Absence of Dbp2p alters both nonsense-mediated mRNA decay and rRNA processing. Mol Cell Biol 2001, 21:7366-7379.

34. Jalal C, Uhlmann-Schiffler $H$, Stahl $H$ : Redundant role of DEAD box proteins $p 68$ (Ddx5) and p72/p82 (Ddx17) in ribosome biogenesis and cell proliferation. Nucleic Acids Res 2007, 35:3590-3601.

35. Maggi LB Jr, Kuchenruether M, Dadey DY, Schwope RM, Grisendi S, Townsend RR, Pandolfi PP, Weber JD: Nucleophosmin serves as a rate-limiting nuclear export chaperone for the Mammalian ribosome. Mol Cell Biol 2008, 28:7050-7065.
36. Bertwistle D, Sugimoto M, Sherr CJ: Physical and functional interactions of the Arf tumor suppressor protein with nucleophosmin/B23. Mol Cell Biol 2004, 24:985-996.

37. Saporita AJ, Chang HC, Winkeler CL, Apicelli AJ, Kladney RD, Wang J, Townsend RR, Michel LS, Weber JD: RNA helicase DDX5 is a p53independent target of ARF that participates in ribosome biogenesis. Cancer Res 2011, 71:6708-6717.

38. Kitamura A, Nishizuka M, Tominaga K, Tsuchiya T, Nishihara T, Imagawa M: Expression of p68 RNA helicase is closely related to the early stage of adipocyte differentiation of mouse 3 T3-L1 cells. Biochem Biophys Res Commun 2001, 287:435-439.

39. Kircher SG, Kim SH, Fountoulakis M, Lubec G: Reduced levels of DEAD-box proteins DBP-RB and p72 in fetal Down syndrome brains. Neurochem Res 2002, 27:1141-1146.

40. Meola G, Jones K, Wei C, Timchenko LT: Dysfunction of protein homeostasis in myotonic dystrophies. Histol Histopathol 2013,

41. Singh C, Haines GK, Talamonti MS, Radosevich JA: Expression of p68 in human colon cancer. Tumour Biol 1995, 16:281-289.

42. Haines GK, Cajulis R, Hayden R, Duda R, Talamonti M, Radosevich JA: Expression of the double-stranded RNA-dependent protein kinase (p68) in human breast tissues. Tumour Biol 1996, 17:5-12.

43. Dosaka-Akita H, Harada M, Miyamoto H, Kawakami Y: [Clinical significance of oncogene product expression in human lung cancer]. Nihon Kyobu Shikkan Gakkai Zasshi 1992, 30:1441-1447.

44. Wang SJ, Zhang C, You Y, Shi CM: Overexpression of RNA helicase p68 protein in cutaneous squamous cell carcinoma. Clin Exp Dermatol 2012, 37:882-888.

45. Lin S, Tian L, Shen H, Gu Y, Li JL, Chen Z, Sun X, James You M, Wu L: DDX5 is a positive regulator of oncogenic NOTCH1 signaling in T cell acute lymphoblastic leukemia. Oncogene 2012,

46. Shin S, Rossow KL, Grande JP, Janknecht R: Involvement of RNA helicases p68 and p72 in colon cancer. Cancer Res 2007, 67:7572-7578.

47. Causevic M, Hislop RG, Kernohan NM, Carey FA, Kay RA, Steele RJ, Fuller-Pace FV: Overexpression and poly-ubiquitylation of the DEADbox RNA helicase p68 in colorectal tumours. Oncogene 2001 20:7734-7743.

48. Wang D, Huang J, Hu Z: RNA helicase DDX5 regulates microRNA expression and contributes to cytoskeletal reorganization in basal breast cancer cells. Mol Cell Proteomics 2012, 11:M111 011932.

49. Fujita T, Kobayashi Y, Wada O, Tateishi Y, Kitada L, Yamamoto Y, Takashima H, Murayama A, Yano T, Baba T, Kato S, Kawabe Y, Yanagisawa J: Full activation of estrogen receptor alpha activation function-1 induces proliferation of breast cancer cells. J Biol Chem 2003, 278:26704-26714.

50. Beier UH, Maune S, Meyer JE, Gorogh T: Overexpression of p68 mRNA in head and neck squamous cell carcinoma cells. Anticancer Res 2006, 26:1941-1946

51. Zhang X, Cairns M, Rose B, O'Brien C, Shannon K, Clark J, Gamble J, Tran N: Alterations in miRNA processing and expression in pleomorphic adenomas of the salivary gland. Int J Cancer 2009, 124:2855-2863.

52. Wang R, Jiao Z, Li R, Yue H, Chen L: p68 RNA helicase promotes glioma cell proliferation in vitro and in vivo via direct regulation of NF-kappaB transcription factor p50. Neuro Oncol 2012, 14:1116-1124.

53. Kitagawa N, Ojima H, Shirakihara T, Shimizu H, Kokubu A, Urushidate T, Totoki Y, Kosuge T, Miyagawa S, Shibata T: Downregulation of the microRNA biogenesis components and its association with poor prognosis in hepatocellular carcinoma. Cancer Sci 2013, 104:543-551.

54. Mooney SM, Grande JP, Salisbury JL, Janknecht R: Sumoylation of p68 and p72 RNA helicases affects protein stability and transactivation potential. Biochemistry 2010, 49:1-10.

55. Nicol SM, Fuller-Pace FV: Analysis of the RNA helicase p68 (Ddx5) as a transcriptional regulator. Methods Mol Biol 2010, 587:265-279.

56. Sambasivan R, Cheedipudi S, Pasupuleti N, Saleh A, Pavlath GK, Dhawan J: The small chromatin-binding protein $\mathrm{p} 8$ coordinates the association of anti-proliferative and pro-myogenic proteins at the myogenin promoter. J Cell Sci 2009, 122:3481-3491.

57. Wilson BJ, Bates GJ, Nicol SM, Gregory DJ, Perkins ND, Fuller-Pace FV: The p68 and p72 DEAD box RNA helicases interact with HDAC1 and repress transcription in a promoter-specific manner. BMC Mol Biol 2004, 5:11.

58. Jiang Z, Guo J, Shen J, Jin M, Xie S, Wang L: The role of estrogen receptor alpha in mediating chemoresistance in breast cancer cells. J Exp Clin Cancer Res 2012, 31:42 
59. Watanabe M, Yanagisawa J, Kitagawa H, Takeyama K, Ogawa S, Arao Y, Suzawa M, Kobayashi Y, Yano T, Yoshikawa H, Masuhiro Y, Kato S: A subfamily of RNA-binding DEAD-box proteins acts as an estrogen receptor alpha coactivator through the $\mathrm{N}$-terminal activation domain (AF-1) with an RNA coactivator, SRA. EMBO J 2001, 20:1341-1352.

60. Wortham NC, Ahamed E, Nicol SM, Thomas RS, Periyasamy M, Jiang J, Ochocka AM, Shousha S, Huson L, Bray SE, Coombes RC, Ali S, Fuller-Pace FV: The DEAD-box protein p72 regulates ERalpha-/oestrogen-dependent transcription and cell growth, and is associated with improved survival in ERalpha-positive breast cancer. Oncogene 2009, 28:4053-4064.

61. Wagner M, Rid R, Maier CJ, Maier RH, Laimer M, Hintner H, Bauer JW, Onder K: DDX5 is a multifunctional co-activator of steroid hormone receptors. Mol Cell Endocrinol 2012, 361:80-91.

62. Clark EL, Hadjimichael C, Temperley R, Barnard A, Fuller-Pace FV, Robson CN: p68/DdX5 supports beta-catenin \& RNAP II during androgen receptor mediated transcription in prostate cancer. PLOS One 2013, 8:e54150.

63. Jahn SC, Law ME, Corsino PE, Rowe TC, Davis BJ, Law BK: Assembly, Activation, and Substrate Specificity of Cyclin D1/Cdk2 Complexes. Biochemistry 2013, 52:3489-3501.

64. Cosgrove RA, Philpott A: Cell cycling and differentiation do not require the retinoblastoma protein during early Xenopus development. Dev Biol 2007, 303:311-324

65. Meijer M, Murray JAH: The role and regulation of D-type cyclins in the plant cell cycle. Plant Mol Biol 2000, 43:621-633.

66. Bourdon JC, Fernandes K, Murray-Zmijewski F, Liu G, Diot A, Xirodimas DP, Saville MK, Lane DP: p53 isoforms can regulate p53 transcriptional activity. Genes Dev 2005, 19:2122-2137.

67. Moore HC, Jordan LB, Bray SE, Baker L, Quinlan PR, Purdie CA, Thompson AM, Bourdon JC, Fuller-Pace FV: The RNA helicase p68 modulates expression and function of the Delta133 isoform(s) of p53, and is inversely associated with Delta133p53 expression in breast cancer. Oncogene 2010, 29:6475-6484.

68. Nicol SM, Bray SE, Black HD, Lorimore SA, Wright EG, Lane DP, Meek DW Coates PJ, Fuller-Pace FV: The RNA helicase p68 (DDX5) is selectively required for the induction of p53-dependent p21 expression and cell-cycle arrest after DNA damage. Oncogene 2013, 32:3461-3469.

69. Yang L, Lin C, Zhao S, Wang H, Liu ZR: Phosphorylation of p68 RNA helicase plays a role in platelet-derived growth factor-induced cell proliferation by upregulating cyclin D1 and c-Myc expression. J Biol Chem 2007, 282:16811-16819.

70. Chen HJ, Hsu LS, Shia YT, Lin MW, Lin CM: The beta-catenin/TCF complex as a novel target of resveratrol in the $\mathrm{Wnt} /$ beta-catenin signaling pathway. Biochem Pharmacol 2012, 84:1143-1153.

71. Arun G, Akhade VS, Donakonda S, Rao MR: mrhl RNA, a long noncoding RNA, negatively regulates Wnt signaling through its protein partner $\mathrm{Ddx} 5 / \mathrm{p} 68$ in mouse spermatogonial cells. Mol Cell Biol 2012, 32:3140-3152.

72. Iqbal S, Zhang S, Driss A, Liu ZR, Kim HR, Wang Y, Ritenour C, Zhau HE, Kucuk O, Chung LW, Wu D: PDGF upregulates Mcl-1 through activation of beta-catenin and HIF-1alpha-dependent signaling in human prostate cancer cells. PLoS One 2012, 7:e30764.

73. Takaoka Y, Shimizu Y, Hasegawa H, Ouchi Y, Qiao S, Nagahara M, Ichihara M, Lee JD, Adachi K, Hamaguchi M, Iwamoto T: Forced expression of miR-143 represses ERK5/c-Myc and p68/p72 signaling in concert with miR-145 in gut tumors of Apc(Min) mice. PLoS One 2012, 7:e42137.

74. Davis BN, Hilyard AC, Lagna G, Hata A: SMAD proteins control DROSHA-mediated microRNA maturation. Nature 2008, 454:56-61.

75. Xu J, Lamouille S, Derynck R: TGF-beta-induced epithelial to mesenchymal transition. Cell Res 2009, 19:156-172.

76. Fuxe J, Vincent T, Garcia de Herreros A: Transcriptional crosstalk between TGF-beta and stem cell pathways in tumor cell invasion: role of EMT promoting Smad complexes. Cell Cycle 2010, 9:2363-2374.

77. Kim Y, Kugler MC, Wei Y, Kim KK, Li X, Brumwell AN, Chapman HA: Integrin alpha3beta1-dependent beta-catenin phosphorylation links epithelial Smad signaling to cell contacts. J Cell Biol 2009, 184:309-322.

78. Kim KK, Wei Y, Szekeres C, Kugler MC, Wolters PJ, Hill ML, Frank JA, Brumwell AN, Wheeler SE, Kreidberg JA, Chapman HA: Epithelial cell alpha3beta1 integrin links beta-catenin and Smad signaling to promote myofibroblast formation and pulmonary fibrosis. J Clin Invest 2009, 119:213-224.

79. Buelt MK, Glidden BJ, Storm DR: Regulation of p68 RNA helicase by calmodulin and protein kinase C. J Biol Chem 1994, 269:29367-29370.

80. Yang L, Yang J, Huang Y, Liu ZR: Phosphorylation of p68 RNA helicase regulates RNA binding by the $\mathrm{C}$-terminal domain of the protein. Biochem Biophys Res Commun 2004, 314:622-630.
81. Ford MJ, Anton IA, Lane DP: Nuclear protein with sequence homology to translation initiation factor elF-4A. Nature 1988, 332:736-738.

82. Yang L, Lin C, Liu ZR: Signaling to the DEAD box-regulation of DEAD-box p68 RNA helicase by protein phosphorylations. Cell Signal 2005, 17:1495-1504.

83. Mooney SM, Goel A, D'Assoro AB, Salisbury JL, Janknecht R: Pleiotropic effects of p300-mediated acetylation on p68 and p72 RNA helicase. J Biol Chem 2010, 285:30443-30452.

84. Jacobs AM, Nicol SM, Hislop RG, Jaffray EG, Hay RT, Fuller-Pace FV: SUMO modification of the DEAD box protein p68 modulates its transcriptional activity and promotes its interaction with HDAC1. Oncogene 2007, 26:5866-5876

85. Yang L, Lin C, Liu ZR: P68 RNA helicase mediates PDGF-induced epithelial mesenchymal transition by displacing Axin from beta-catenin. Cell 2006, 127:139-155.

86. He X: Unwinding a path to nuclear beta-catenin. Cell 2006, 127:40-42.

87. Wang H, Gao X, Yang JJ, Liu ZR: Interaction between p68 RNA helicase and $\mathrm{Ca} 2+-$ calmodulin promotes cell migration and metastasis. Nat Commun 2013, 4:1354.

88. Le Dily F, Metivier R, Gueguen MM, Le Peron C, Flouriot G, Tas P, Pakdel F: COUP-TFI modulates estrogen signaling and influences proliferation, survival and migration of breast cancer cells. Breast Cancer Res Treat 2008, 110:69-83.

89. Mi J, Liu Y, Rabbani ZN, Yang Z, Urban JH, Sullenger BA, Clary BM: In vivo selection of tumor-targeting RNA motifs. Nat Chem Biol 2010, 6:22-24.

90. Jiang GM, Wang HS, Zhang F, Zhang KS, Liu ZC, Fang R, Wang H, Cai SH, $\mathrm{Du} \mathrm{J}$ : Histone deacetylase inhibitor induction of epithelial-mesenchymal transitions via up-regulation of Snail facilitates cancer progression. Biochim Biophys Acta 1833, 2013:663-671.

91. Carter CL, Lin C, Liu CY, Yang L, Liu ZR: Phosphorylated p68 RNA helicase activates Snail 1 transcription by promoting HDAC1 dissociation from the Snail1 promoter. Oncogene 2010, 29:5427-5436.

92. Peinado $\mathrm{H}$, Ballestar E, Esteller M, Cano A: Snail mediates E-cadherin repression by the recruitment of the $\operatorname{Sin} 3 \mathrm{~A} /$ histone deacetylase 1 (HDAC1)/HDAC2 complex. Mol Cell Biol 2004, 24:306-319.

93. Tomao F, Papa A, Rossi L, Strudel M, Vici P: Lo Russo G. Tomao S: Emerging role of cancer stem cells in the biology and treatment of ovarian cancer: basic knowledge and therapeutic possibilities for an innovative approach. J Exp Clin Cancer Res 2013, 32:48.

94. Yang L, Lin C, Liu ZR: Phosphorylations of DEAD box p68 RNA helicase are associated with cancer development and cell proliferation. Mol Cancer Res 2005, 3:355-363.

95. Dey H, Liu ZR: Phosphorylation of p68 RNA helicase by p38 MAP kinase contributes to colon cancer cells apoptosis induced by oxaliplatin. BMC Cell Biol 2012, 13:27.

96. Yang L, Lin C, Sun SY, Zhao S, Liu ZR: A double tyrosine phosphorylation of P68 RNA helicase confers resistance to TRAIL-induced apoptosis. Oncogene 2007, 26:6082-6092.

doi:10.1186/s13046-014-0064-y

Cite this article as: Dai et al:: P68 RNA helicase as a molecular target for cancer therapy. Journal of Experimental \& Clinical Cancer Research 2014 33:64

\section{Submit your next manuscript to BioMed Central and take full advantage of:}

- Convenient online submission

- Thorough peer review

- No space constraints or color figure charges

- Immediate publication on acceptance

- Inclusion in PubMed, CAS, Scopus and Google Scholar

- Research which is freely available for redistribution 